\title{
EFFECTS OF AGE/WEIGHT AND CASTRATION ON FATTY ACIDS COMPOSITION IN PORK FAT AND THE QUALITIES OF PORK AND PORK FAT IN MEISHAN X LARGE WHITE PIGS
}

Teye $\mathbf{G A}^{\mathbf{1}^{*}}$

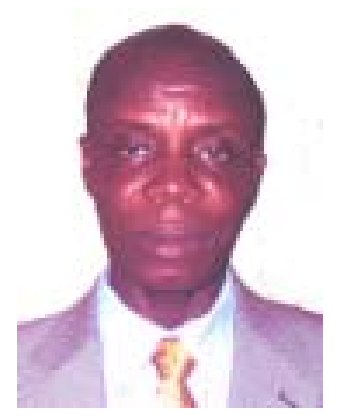

Teye Gabriel

*Corresponding author email: teye.gabriel@yahoo.com

${ }^{1}$ Department of Animal Science, University for Development Studies, Box TL 1882 Tamale, Ghana. 


\section{ABSTRACT}

This study investigates the effects of age/weight and castration on the fatty acid composition and the qualities of pork and pork fat. Thirty hybrid male pigs $(50 \%$ Meishan x 50\% Large White) were used. Fifteen were castrated within the first two days of age and the other fifteen remained entire. At 12 weeks of age, the pigs were divided into three groups, each consisting of five castrates and five boars. Animals were fed a basic standard commercial pelleted diet for 30,60 or 90 days and then slaughtered, so that the actual age of the pigs at slaughter was 114, 144 and 174 days respectively. Parameters considered for carcass quality were carcass weight, initial $\mathrm{pH}$ (pH45) and ultimate (final) $\mathrm{pH}(\mathrm{pHu})$, and $\mathrm{P} 2$ backfat thickness. For pork and pork fat qualities, the following parameters were considered: backfat firmness, slip point, sensory attributes and adipose tissue fatty acid composition. Increasing age/weight significantly increased carcass weight and $\mathrm{P} 2$ backfat thickness $(\mathrm{P}<0.01)$ and had a greater influence on tenderness and juiciness than sex $(\mathrm{P}<0.001)$. Fat firmness and slip point increased significantly with increasing age/weight from 30 to 90 days $(\mathrm{P}<0.001)$. Increasing age/weight resulted in increased concentrations of Stearic, $(\mathrm{C} 18: 0)$ and total saturated fatty acids $(\mathrm{SFA})(\mathrm{P}<0.01)$ but significantly lowered the concentrations of linoleic acid (18:2), linolenic (18:3) and total polyunsaturated fatty acids (PUFA) $(\mathrm{P}<0.001)$. Castration increased total lipid by $9.8 \mathrm{~g}(\mathrm{P}<0.01)$, made backfat firmer from 60 to 90 days $(\mathrm{P}<0.05)$, but significantly lowered abnormal odour in lean muscle $(\mathrm{P}<0.001)$ and the concentration of polyunsaturated fatty acids $(\mathrm{P}<0.01)$. The nutritional quality index of backfat declined significantly with increasing age $(\mathrm{P}<0.01)$ and also in castrates than boars $(\mathrm{P}<0.05)$. Backfat thickness, slip point and fat firmness/hardness had good positive correlations with the major SFA (C16:0 and C18:0), C18:0/C18:2 ratio, total lipid and total SFA, but good negative correlations with the PUFAs. Both boars and castrates can produce quality pork and pork fat if they are slaughtered at suitable ages before the boars attain the threshold level for boar taint and before the castrates become excessively fat such that their meat may not appeal to health conscious consumers.

Key words: pigs, backfat, fatty acids, castration, quality 


\section{INTRODUCTION}

Meat and meat product qualities can be seriously affected by the fatty acid composition of the muscle and adipose tissues. The composition and quality of fat in pigs can be manipulated through extrinsic and intrinsic factors. For decades, researchers and producers have been using factors such as age or weight at slaughter, sex, diet and genetics to modify meat and fat qualities to produce meat products to meet the demand of consumers [1]. It will not be possible to generalise a universally agreed slaughter weight for pigs because the appropriate slaughter weights depend on the economic considerations such as feed costs and market [2].

Castration of males has been widely practised in animal production over the years for several reasons including the ease of controlling, removal of undesirable odour (boar taint) and to deposit fatty tissues [3]. Though animal welfare campaigners in some countries are against castration, it is being practiced in other countries where consumers dislike the offensive odour and flavour of boar taint [4]. Similarly, castration is being practiced in developing countries such as Ghana where it is used to produce pork without taint to satisfy consumers' preferences [5]. However, recent changes of consumer attitudes towards a higher demand for leaner meat coupled with the advantages of producing entire males which include lower cost, better feed conversion efficiency and better growth rate have led to a rising use of boars for pork production $[4,6,7]$. The unsaturated fatty acid fraction of backfat is higher in entire males than in castrates $[4,8]$. Higher concentrations of water and unsaturated fatty acids in the adipose tissue of entire males make their fat softer $[4,9]$, which results in the problem of fat separation from the muscle in lean entire males $[6,10,11]$ causing poor processing qualities with higher susceptibility to oxidative rancidity $[4,12,13]$.

During growth, there is an increased proportion of energy available for fat deposition in pigs resulting in increased de novo fatty acid synthesis of mainly palmitic (16:0) and stearic (18:0) acids [14, 15]. The concentration of linoleic (C18: 2) acid declines as these saturated fatty acids increase. Thus increases in body weight/age are accompanied by increased deposition of adipose tissue and muscle lipid [16], with a corresponding decrease in moisture and protein [17, 18]. The aim of this study, therefore, was to investigate the effect of age/weight and castration on the fatty acid composition and the qualities of pork and pork fat in pigs.

\section{MATERIALS AND METHOD}

\section{Animals and diets}

Thirty hybrid male pigs (50\% Meishan x 50\% Large White) were used. Fifteen were castrated within the first two days of age and the other fifteen remained uncastrated. At 12 weeks of age, the pigs were transferred to the University of London Wye College Pig Unit and divided into three groups, each consisting of five castrates and five boars. All groups were allocated to pens fitted with electronic (FIRE) feeders and freely available water. Animals were fed a basic standard commercial pelleted diet (BOCM Pauls Ltd., Ipswich, Suffolk) for 30,60 or 90 days and then slaughtered, so 
that the actual age of the pigs at slaughter was 114, 144 and 174 days, respectively. The diet contained the following ingredients in descending order by weight: barley, wheat, low glucosinolate rape seed extract, wheat feed, beans, soya bean extract, vegetable oils, calcium carbonate, lysine, salt, dicalcium phosphate and vitaminmineral premix. The proximate composition of the basic diet was $14 \mathrm{MJ} / \mathrm{kg}$ digestible energy, $170 \mathrm{~g} / \mathrm{kg}$ crude protein and $1.1 \mathrm{~g} / \mathrm{kg}$ lysine. All diets were given on an ad libitum basis. The animals were transferred and slaughtered at the abattoir of University of Bristol.,UK.

\section{Sample collection}

Hot carcass weight, initial $\mathrm{pH}(\mathrm{pH} 45)$, taken 45 minutes after slaughter and $\mathrm{P} 2$ backfat thickness measurements at $5 \mathrm{~cm}$ from the mid-line at the last rib position were taken before placing the carcases overnight in a standard chiller at $1^{\circ} \mathrm{C}$. Twenty-four hours after slaughter, carcasses were removed from the chiller and butchered after measuring cold carcass weights, final $\mathrm{pH}(\mathrm{pHu})$ and fat firmness. The right $\mathrm{m}$. longissimus dorsi (LD) was removed and from the anterior end, a chop of about 2.5 $\mathrm{cm}$ thickness was cut and vacuum-packed immediately after butchering for fatty acid analysis. The remaining sections of the LD for taste panel were vacuum-packed and condition for 10 days in a chiller at $1^{\circ} \mathrm{C}$.

\section{Measurements}

\section{Sensory analysis}

Ten female assessors who performed the sensory analyses were selected in accordance with the recommendations of the British Standard Institution [19]. Loin samples were thawed initially at room temperature and then stored overnight in a refrigerator set at $1^{\circ} \mathrm{C}$. The thawed loins were sliced into chops of $2.5 \mathrm{~cm}$ thickness and griddled to an internal temperature of $72.5^{\circ} \mathrm{C}$ (measured by a thermocouple probe) using a Lincat griddle (Lincat model GS7, Lincat Ltd, Lincoln, UK). During the cooking period the slices were turned over every three minutes. Two rectangular samples were cut from each chop, wrapped in labelled pieces of foil and presented to the assessors. Assessors used category scales (1-8) to evaluate pork odour (1extremely weak, 8-extremely strong), texture (1-extremely tough, 8-extremely tender), juiciness (1- extremely dry, 8 - extremely juicy) pork flavour (1- extremely weak, 8- extremely strong), abnormal flavour (1- extremely weak, 8- extremely strong) and overall liking (1- dislike very much, 8 - like very much).

\section{Fat firmness}

The firmness/hardness of the backfat was determined by means of a custom-made, hand-held digital penetrometer designed and built at the former Meat Research Institute, Langford, UK. The probe was calibrated daily by pressing it against a flat metal plate to read 1000units. A value close to 1000 represents 'very hard fat'. Measurements were taken thrice at two sites, shoulder and loin regions at $2 \pm 0.5^{\circ} \mathrm{C}$. The probe of the penetrometer was placed at right angles to the surface of the inner fat layer subcutaneous fat which is exposed when the carcass is split.

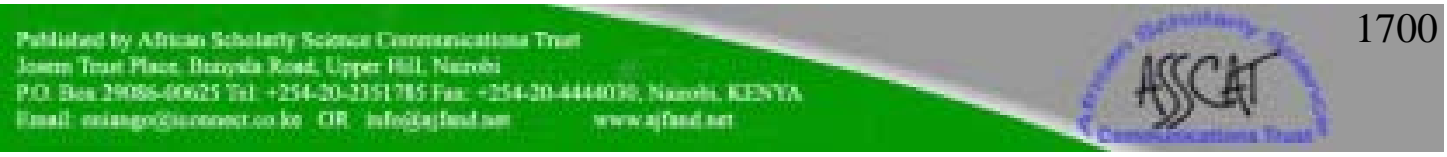




\section{Slip point of fat}

The slip point (melting point in an open capillary tube) of subcutaneous fat from the loin was determined by a slightly modified version of the method outlined by the British Standards Institution [20]. It involved the immersion of glass capillary tubes containing solid fat columns, at a specified depth in deionised and degassed water in a transparent water bath. The initial temperature of the water was less than $15^{\circ} \mathrm{C}$. The rise in water temperature approximately $1{ }^{\circ} \mathrm{C}$ per minute was monitored using a digital thermometer (Comark $9001 \mathrm{UK}$ ). The temperatures at which the fat columns were observed to start rising in the capillary tube were noted as the slip point of each sample. After each test, the hot water was replaced with fresh cold water below $15^{\circ} \mathrm{C}$ before the next batch of samples was tested. .

\section{Fatty acid composition of adipose tissue}

The extraction of lipid from the subcutaneous adipose tissue and determination of fatty acid composition was according to a routine procedure [21], as follows: samples were thawed, trimmed of any muscle, skin and connective tissue and approximately $1 \mathrm{~g}(0.98-1.05)$ cubes of fat were cut across the outer and inner layers. Lipids were extracted into chloroform, containing 2, 6-di-tert-butyl-p-cresol as an antioxidant and anhydrous sodium sulphate was added to remove water. Duplicate $1 \mathrm{~g}$ sub-samples were hydrolysed for $1 \mathrm{~h}$ at $60^{\circ} \mathrm{C}$ with $2 \mathrm{M} \mathrm{KOH}$ in $50 \%$ aqueous methanol, containing hydroquinone as an antioxidant, and a known amount of $\mathrm{C} 21: 0$ as an internal standard. After allowing samples to cool, distilled water was added and nonsaponifiable lipids were extracted into light petroleum ether $\left(40-60^{\circ}\right)$ and discarded. The hydrolysates were acidified with $10 \mathrm{~N} \mathrm{H}_{2} \mathrm{SO}_{4}$ and fatty acids were extracted into petroleum ether. Methyl esters were prepared using diazomethane in diethyl ether, and analysed by gas chromatography. Analysis was performed using a temperatureprogrammed run on a Fisons Mega Series 5160 GC equipped with a CP Sil88 WCOT capillary column (50m x $0.25 \mathrm{~mm}$ internal diameter, Chrompak UK Ltd, UK), a split/splitless injector set with a split of 50:1, and a flame-ionisation detector. Helium was used as the carrier gas, and fatty acids were identified by comparison with standards purchased from Sigma UK. Quantification was achieved by use of the internal standard added prior to hydrolysis, and the linearity of the detector response was tested by using a reference monoenoic FAME mix (FAME \#5, Thames Restek UK). The results were expressed as $\mathrm{g} / 100 \mathrm{~g}$ fatty acid (\% by weight).

\section{Statistical analysis}

The statistical analysis was performed using general linear model (GLM) of either MINITAB version 13.0 (MINITAB, PA, USA) or SPSS Release 12.0 in examining the effects of sex (castrate and boar) and weight/age (days on trial). Where the data involved the three age groups 30,60 and 90 days, polynomial contrasts were used (linear and quadratic) to examine the effect of days on the outcome variables. The analysis was performed either as a $3 \times 2$ factorial (where all the 3 age groups are or were involved) or as a $2 \times 2$ factorial design (where only 60 and 90 days were considered). The taste panel data were analysed using sex, age and assessors as the main factors and panels treated as a block structure for five replications. Where there

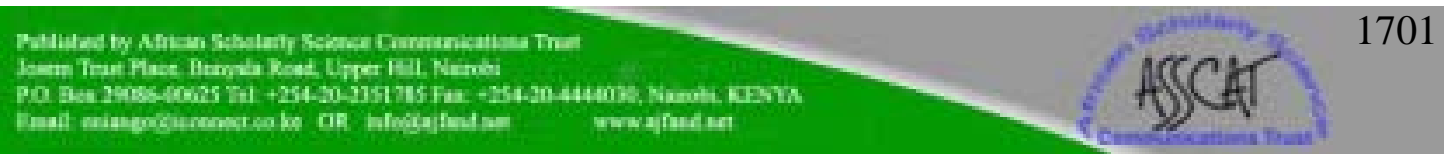


were significant interactions between the main effects (age and sex), the standard error of difference, variances ratio and significance were recalculated.

\section{RESULTS}

\section{Carcass characteristics}

There was no significant effect of sex on carcass weight, $\mathrm{pH}$ and $\mathrm{P} 2$ backfat thickness (P> 0.05) (Table1). Increasing age/weight significantly increased carcass weight and $\mathrm{P} 2$ backfat thickness $(\mathrm{P}<0.01)$ (Table1); however, it had no effect on initial $\mathrm{pH}_{45}$ and ultimate $\mathrm{pHu}$ (24 hours) in the loin muscle ( $m$ longissimus dorsi) (Table1).

\section{Meat quality}

\section{Eating quality of loin chop}

Sex and increasing age/weight did not have any adverse effect on pork odour of the cooked lean and fat. Abnormal odour was, however, significantly affected by sex in the lean muscle (Table2) $(\mathrm{P}<0.001)$. There were significant interactions between the effects of sex and age on abnormal odour (Table 3) such that as the age of the boars increased, the abnormal odour also increased significantly $(\mathrm{P}<0.001)$. Age had a greater influence on tenderness and juiciness than sex $(\mathrm{P}<0.001)$. In contrast, sex had a significant effect on juiciness but not on tenderness $(\mathrm{P}<0.05)$. Again, there were significant interactions between the effects of sex and age on flavour liking $(\mathrm{P}<0.001)$ and overall liking $(\mathrm{P}<0.01)$ (Table3).

\section{Backfat qualities}

\section{Fat firmness/hardness and slip (melting) point}

The effects of age/weight and sex on fat firmness or hardness at $2{ }^{\circ} \mathrm{C}$ are shown in Table 4. There was a significant effect of increasing age/weight on fat firmness from 30 to 90 days $(\mathrm{P}<0.001)$. Gender status also had an effect on fat firmness, with castrate fat being firmer in both shoulder and loin $(\mathrm{P}<0.05)$. Initial statistical analyses indicated significant differences between shoulder and loin fat, with shoulder fat being firmer in both sexes $(\mathrm{P}<0.001)$. Age/weight had a significant effect on slip point $(\mathrm{P}<0.001)$ but sex did not (Table 4). The slip point for the 90 days group was significantly higher than the other groups.

\section{Adipose tissue total lipid and fatty acid composition.}

Results for subcutaneous total lipid are expressed as a proportion of the tissues (g per $100 \mathrm{~g}$ tissue) and the fatty acids fractions are expressed as a proportion of the total fatty acids present in the adipose tissue(e.g. fatty acid per $100 \mathrm{~g}$ total fatty acids) (Table 5). Age/weight at slaughter did not have a significant effect on the weight of total lipid but total lipid in castrates was significantly higher $(+9.8 \mathrm{~g})$ than in boars $(\mathrm{P}<0.05$. The fatty acid profile shows that the concentration of $\mathrm{C} 18: 0$ and the total saturated fatty acids increased linearly with increasing age/weight $(\mathrm{P}<0.01)$ whilst sex had no effect on any the saturated fatty acids (SFA; Lauric; 12:0, Myristic; 14:0, Palmitic, 16:0 and Stearic, 18:0 acids) and hence on total SFA. There was a significant downward linear response in the concentration of pamitoleic acid (16:1) 
with increasing age/weight from 30 to 90 days $(\mathrm{P}<0.001)$ but sex had no effect on 16:1 concentration.

Both age/weight and sex had significant effects on the concentrations of linoleic acid (18:2), linolenic (18:3) and total polyunsaturated fatty acids (PUFA) (Tables 5). There were significant linear decrease in the concentration of PUFAs with increasing age/weight $(\mathrm{P}<0.001)$. Similarly, castrates had a much lower $(\mathrm{P}<0.01)$ concentration of $18: 2$ than boars $(16.40 \mathrm{~g}$ vs. $19.69 \mathrm{~g})$. Again, the concentration of $18: 3$ was significantly lower in castrates $(\mathrm{P}<0.05)$. The concentration of total PUFA was also significantly lower in the castrates than in boars $(\mathrm{P}<0.01)$.

Both fat hardness index (18:0/18:2 ratio) and nutritional quality index ( $\mathrm{P}: \mathrm{S}$ ratio) were influenced linearly by age/weight and sex. The hardness index indicates that the 90 days fat was the firmest $(\mathrm{P}<0.001)$. The castrates fat was also significantly firmer $(\mathrm{P}<0.0)$ than boars. There was a significant decline in nutritional quality index with increasing age $(\mathrm{P}<0.01)$, and was severer in castrates than boars $(\mathrm{P}<0.05)$.

\section{DISCUSSION}

\section{Effects of age/weight and sex on carcass quality}

Increasing age/weight resulted in an increased carcass weight and P2 backfat thickness due to growth and development resulting in the accumulation of new tissues (bone, muscle and fat). Age/weight had no effect on the $\mathrm{pH}$ of LD, which contradicts the reports in which the ultimate $\mathrm{pH}$ was reduced as the slaughter weight increased from 100 to $160 \mathrm{~kg}$ [17]. This suggested that all the pigs were less aggressive and did not fight during holding. There was no effect of sex on carcass weight, $\mathrm{pH}$ of LD, and backfat thickness. Several authors have also reported this lack of the effect of sex on carcass weights $[3,6,22]$. This result suggests that the reported efficient and faster growth of boars may not be an absolute advantage over castrates since both sexes eventually produced similar carcass weights $[4,7,23]$.

\section{Meat and fat qualities}

Age/weight did not affect the tenderness of the loin muscle. This result contradicts one in which increased in shear force with increasing weight between 110 and $140 \mathrm{~kg}$ was observed [24]. The similarity in muscle texture in both sexes and among ages suggests that any differences in processing characteristics should be due to differences in adipose tissue composition and quality. With the exception of odour and juiciness, there was no effect of gender on other sensory attributes. Similar reports of no differences in juiciness and sometimes tenderness between boar and other genders were made by many authors [9, 10, 25]. Fatness could be responsible for castrates being juicier than boars. One of the main disadvantages perhaps to the butcher/processor, of using entire males for pork production was manifested in this study where abnormal odour was significantly higher in boar fat and became severe with increasing age/weight. It has been observed that fat from boars had a higher level of abnormal odour than fat from gilts [23]. The result shows an interaction between 
sex and age to cause problems of off-flavours and dislike of tainted pork as weight increases in boars.

The results show that fat from castrates is firmer than fat from boars. The high propensity of castrates to deposit fat [4], a phenomenon often associated with increasing degree of saturation of fatty acids, is probably responsible for the castrates' fat being firmer. Backfat from entire males is known to be softer due to a high water and unsaturated fatty acid content $[4,9,11]$. Age/weight had a marked effect on the slip point of backfat (Table 4), a response that reflects the pattern of fat hardness. As the pigs grew older and fatter from 30 and 90days, their fat became firmer and the melting point increased by $3.9^{\circ} \mathrm{C}$. A similar result whereby melting point increased with increasing hardness of porcine fat has been reported [26].

\section{Effects of age/weight and sex on fatty acid composition of adipose tissue}

Age/weight did not significantly affect the total lipid content of subcutaneous tissues, which deviates from recorded trends where lipid deposition tends to increase as body weight increases [16]. Perhaps, these animals were still in an active state of development and did not attain the point of rapid deposition of fat before they were slaughtered. It was indicated that in modern pigs with a high potential for lean growth, the weight at which rapid fat deposition occurs is delayed [27]. The significant effect of sex on total lipid obtained in this study agrees with an observed increased fatness due to castration [3]

The minimal effect of age/weight on the SFA fraction shows that the effect of increasing age/weight on saturation $[15,28]$ is less applicable here due to smaller effect on fatness. Whilst age/weight had no effect on the concentration of oleic acid (18:1n-9), the major MUFA, the concentration of palmitoleic acid (16:1) was markedly $(\mathrm{P}<0.001)$ reduced with increasing age/weight. It seemed the mechanism that caused the sudden decline in the level of C16:1 from 30 to 60 days became inactive thereafter and did not affect $\mathrm{C} 18: 1$ at all. Castration unexpectedly increased the concentration of $\mathrm{C} 18: 1$, an unsaturated fatty acid. The possible reason for this is that increasing C18:0 productions provide more substrate for desaturase enzymes which convert $\mathrm{C} 18: 0$ to $\mathrm{C} 18: 1$.

The major differences among the age/weight groupings and between the two genders in the fatty acid composition were in the PUFA fraction of the fatty acid profile. There were sharp decline in the levels of C 18:2, C18:3 and total PUFA from 60 to 90 days (Table 5). This shows a tendency towards a rapid degree of saturation of adipose tissue with increasing age/weight, a pattern that is consistent with other reports [14, 15, 27, and 28]. As reported elsewhere the lipid from boars contained more unsaturated fatty acids than that from of castrates $[6,9,29]$, and explains why the boar fat was softer than the castrate fat.

Again, there was a sharp change in the hardness index (18:0/18:2) from 60 to 90 days, which indicates an increase in hardness with increasing age/weight. A reduction in the proportion of unsaturated fatty acids such as C18:2 and an increase in the

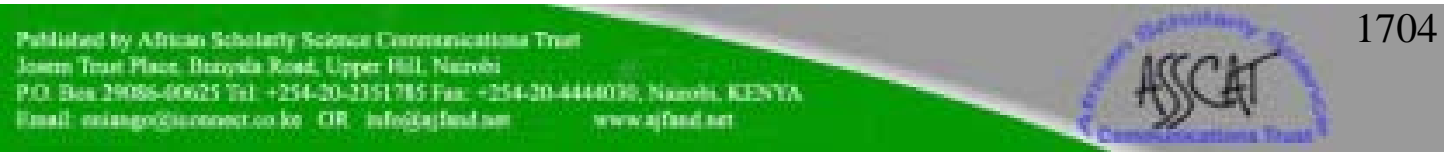


proportion of saturated fatty acids such as C18:0 due to de novo synthesis of fat as the pigs become heavier [14, 15, 28], could be responsible for this sharp rise in fat firmness with increasing age/weight. Similarly, the higher firmness index in the castrates reflects the changes in the fatty acid profile towards increasing proportion of SFA with a corresponding decrease in the proportion of PUFA which makes the castrate fat firmer $[6,9,29]$. Though there was a marked decline in the nutritional index (P: S ratios) with age from 60 to 90 days and in castrates, all the values were above the minimum recommended ratio of 0.4 [1], which indicates that the meat is healthy for human consumptions with regard to its fatty composition.

\section{CONCLUSION}

The results from this experiment have shown that both boars and castrates can be used for the production of quality pork and pork fat suitable for human consumption. This is with regard to their comparable fatty acid profile and P:S ratios which was above the minimum of 0.4 recommended by experts to prevent heart diseases. The amount of fat increased with increased age/weight, it became more saturated and firmer especially the thicker shoulder fat. Sex was more important in sensory quality as there were less abnormal odours in castrate meat. Clearly, it is possible to produce high quality pork and pork fat from both boars and castrate if they can be slaughtered at suitable ages. That is, before the boars attain the threshold level for boar taint and before the castrates become excessively fat such that their meat may not appeal to health conscious consumers.

\section{ACKNOWLEDGEMENTS}

The study was conducted with financial support from the Biological and Biotechnology Sciences Research Council (BBSRC) in the UK. The author is indebted to all the scientific and laboratory staff of the Division of Farm Animal Science, University of Bristol who assisted in this work and also grateful to staff of the University of London Wye College Pig Unit at Ashford in managing the animals. 
Table 1: Effect of days on trial and sex on carcass characteristics

\begin{tabular}{|c|c|c|c|c|c|c|c|c|c|c|}
\hline & \multicolumn{3}{|c|}{ Days on trial } & \multicolumn{2}{|c|}{$\begin{array}{c}\text { Polynomial } \\
\text { contrasts }\end{array}$} & \multicolumn{2}{|c|}{ Sex } & \multirow[b]{2}{*}{$\mathrm{sed}^{\S}$} & \multirow[b]{2}{*}{$\mathrm{F}$} & \multirow[b]{2}{*}{ sig. } \\
\hline & 30 & 60 & 90 & linear & quadratic & boar & castrate & & & \\
\hline CCwt (kg) & 32.9 & 50.6 & 71.9 & $* * *$ & ns & 51.3 & 52.4 & 3.17 & 0.09 & ns \\
\hline $\mathrm{P} 2 \mathrm{FT}(\mathrm{mm})$ & 10.9 & 12.9 & 16.1 & $* *$ & $\mathrm{~ns}$ & 12.2 & 14.4 & 1.47 & 2.19 & $\mathrm{~ns}$ \\
\hline $\mathrm{pH}_{45}$ & 6.1 & 6.1 & 6.1 & ns & ns & 6.0 & 6.1 & 0.14 & 2.19 & $\mathrm{~ns}$ \\
\hline $\mathrm{pHu}$ & 5.5 & 5.5 & 5.5 & $\mathrm{~ns}$ & ns & 5.5 & 5.5 & 0.03 & 0.01 & ns \\
\hline
\end{tabular}

ns: not significant; $* *: \mathrm{P} \leq 0.01 ; * * *: \mathrm{P} \leq 0.001$;

$\S$ standard error of difference; CCwt: Cold carcass weight;

FT: fat thickness

Table 2: Effect of age /weight and sex on eating quality of grilled loin chop and backfat Days on trial Sex

\begin{tabular}{|c|c|c|c|c|c|c|c|c|c|}
\hline & & \multirow[b]{2}{*}{$\mathrm{sed}^{\S}$} & \multirow[b]{2}{*}{ sig } & & \multirow[b]{2}{*}{$\mathrm{sed}^{\S}$} & \multirow[b]{2}{*}{ Sig. } \\
\hline & 30 & 60 & 90 & & & Boar & castrate & & \\
\hline \multicolumn{10}{|l|}{$\overline{\text { Fat }}$} \\
\hline Pork odour & 3.2 & 3.3 & 3.1 & 0.237 & ns & 3.1 & 3.3 & 0.193 & ns \\
\hline Abnormal odour ${ }^{\dagger}$ & 2.9 & 3.3 & 3.7 & 0.548 & ns & 3.8 & 2.8 & 0.448 & ns \\
\hline \multicolumn{10}{|l|}{ Lean } \\
\hline Pork odour & 3.1 & 3.0 & 3.2 & 0.225 & $\mathrm{~ns}$ & 3.1 & 3.2 & 0.184 & $\mathrm{~ns}$ \\
\hline Abnormal odour & 2.6 & 2.9 & 3.0 & 0.230 & ns & 3.1 & 2.5 & 0.188 & $* *$ \\
\hline Tenderness & $4.5^{\mathrm{b}}$ & $4.3^{\mathrm{b}}$ & $3.5^{\mathrm{a}}$ & 0.181 & $* * *$ & 4.3 & 4.0 & 0.148 & ns \\
\hline Juiciness & $4.1^{\mathrm{b}}$ & $4.2^{\mathrm{b}}$ & $3.5^{\mathrm{a}}$ & 0.178 & $* * *$ & 3.8 & 4.1 & 0.145 & $*$ \\
\hline Flavour liking $^{\dagger}$ & 4.1 & 3.9 & 3.6 & 0.532 & ns & 3.5 & 4.1 & 0.162 & $\mathrm{~ns}$ \\
\hline Overall liking $^{\dagger}$ & 3.8 & 3.7 & 3.2 & 0.449 & ns & 3.4 & 3.7 & 0.367 & ns \\
\hline
\end{tabular}

Means in a row with the same superscript are not significantly different. Ns: not significant; $*: \mathrm{P} \leq 0.05 ; * *: \mathrm{P} \leq 0.01 ; * * * \mathrm{P} \leq 0.001^{\S}$ standard error of difference (sed);

${ }^{\dagger}$ Significant interaction between main effects see table 3 
Table 3: Effect of the interaction between sex and age on eating quality of loin chop

\begin{tabular}{lccccccccc}
\hline & \multicolumn{3}{c}{ Boar } & & \multicolumn{3}{c}{ Castrate } & & \multicolumn{2}{c}{$\begin{array}{c}\text { significance of } \\
\text { Day on trial }\end{array}$} & 30 & 60 & 90 & 30 & 60 & 90 & & sed $^{\S}$ & interaction \\
\hline Abnormal & & & & & & & & $*$ \\
odour of fat & $3.0^{\mathrm{a}}$ & $3.8^{\mathrm{b}}$ & $4.6^{\mathrm{c}}$ & $2.7^{\mathrm{a}}$ & $2.8^{\mathrm{a}}$ & $2.7^{\mathrm{a}}$ & 0.348 & $* *$ \\
Flavour liking & $4.2^{\mathrm{c}}$ & $3.5^{\mathrm{ab}}$ & $3.0^{\mathrm{a}}$ & $3.9^{\mathrm{bc}}$ & $4.3^{\mathrm{c}}$ & $4.2^{\mathrm{c}}$ & 0.280 & $* * *$ \\
Overall liking & $4.1^{\mathrm{d}}$ & $3.4^{\mathrm{ab}}$ & $2.9^{\mathrm{a}}$ & $3.6^{\mathrm{bcd}}$ & $4.0^{\mathrm{cd}}$ & $3.5^{\mathrm{bc}}$ & 0.268 & $* *$ \\
\hline
\end{tabular}

Means in a row with the same superscript are not significantly different.

$* *: \mathrm{P} \leq 0.01 ; * * * \mathrm{P} \leq 0.001^{\S}$ standard error of difference (sed)

Table 4: Effect of age /weight and sex on shoulder and loin fat firmness/ hardness of fat at $2^{\circ} \mathrm{C}$ as determined by a Penetrometer probe and slip (melting) point of backftat

\begin{tabular}{|c|c|c|c|c|c|c|c|c|c|c|}
\hline & \multicolumn{3}{|c|}{ Days on trial } & \multicolumn{2}{|c|}{$\begin{array}{l}\text { Polynomial } \\
\text { contrasts }\end{array}$} & \multicolumn{2}{|c|}{ Sex } & \multirow[b]{2}{*}{$\operatorname{sed}^{\S}$} & \multirow[b]{2}{*}{$\mathrm{F}$} & \multirow[b]{2}{*}{ sig } \\
\hline & 30 & 60 & 90 & linear & quadratic & boar & castrate & & & \\
\hline \multicolumn{11}{|c|}{ Shoulder fat } \\
\hline $2{ }^{0} \mathrm{C}$ & 462 & 590 & 751 & $* * *$ & ns & 538 & 664 & 44.9 & 7.9 & $* *$ \\
\hline \multicolumn{11}{|l|}{$\underline{\text { Loin fat }}$} \\
\hline $2{ }^{0} \mathrm{C}$ & 268 & 505 & 595 & $* * *$ & ns & 369 & 543 & 63.9 & 7.6 & $*$ \\
\hline $\begin{array}{l}\text { Slip } \\
\text { point }\left({ }^{0} \mathrm{C}\right)\end{array}$ & 26.3 & 26.0 & 29.9 & $* * *$ & $*$ & 27.0 & 27.9 & 1.04 & 1.0 & ns \\
\hline
\end{tabular}

Ns: not significant; $*$ : $\mathrm{P} \leq 0.05 ; * * \mathrm{P} \leq 0.01 ; * * * \mathrm{P} \leq 0.001$

${ }^{\S}$ standard error of difference; 


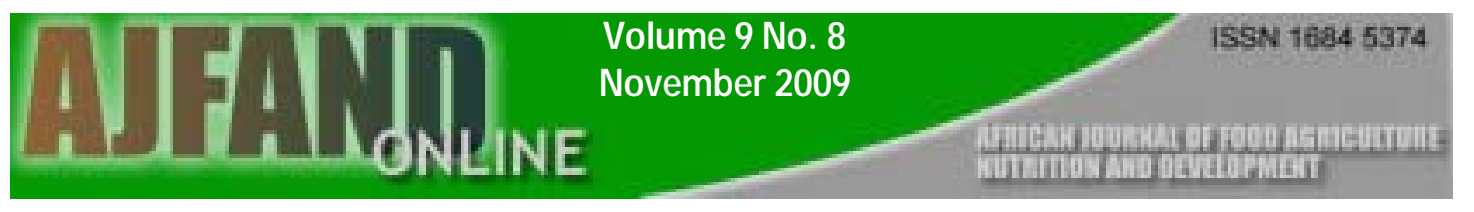

Table 5: The effects age/weight and sex on total lipid and fatty acid composition in the backfat (g per $100 \mathrm{~g}$ fatty acid)

\begin{tabular}{|c|c|c|c|c|c|c|c|c|c|c|}
\hline \multirow{2}{*}{\multicolumn{2}{|c|}{30}} & \multicolumn{2}{|c|}{ Days on trial } & \multicolumn{2}{|c|}{$\begin{array}{l}\text { Polynomial } \\
\text { contrasts }\end{array}$} & \multicolumn{2}{|c|}{ Sex } & \multirow[b]{2}{*}{$\operatorname{sed}^{\S}$} & \multirow[b]{2}{*}{$\mathrm{F}$} & \multirow[b]{2}{*}{ sig } \\
\hline & & 60 & 90 & linea & dratic & boar & castrate & & & \\
\hline $\mathrm{C} 12: 0$ & 0.1 & 0.1 & 0.1 & ns & ns & 0.1 & 0.1 & 0.09 & 3.41 & $\mathrm{~ns}$ \\
\hline C14:0 & 1.4 & 1.3 & 1.3 & ns & ns & 1.3 & 1.3 & 0.04 & 0.19 & $\mathrm{~ns}$ \\
\hline C16:0 & 21.5 & 21.9 & 22.5 & ns & ns & 21.8 & 22.2 & 0.48 & 0.47 & $\mathrm{~ns}$ \\
\hline C16:1 & 3.2 & 2.8 & 2.5 & $* * *$ & ns & 2.9 & 2.8 & 0.15 & 0.74 & $\mathrm{~ns}$ \\
\hline C18:0 & 9.3 & 9.7 & 11.1 & $* *$ & ns & 9.9 & 10.2 & 0.51 & 0.50 & $\mathrm{~ns}$ \\
\hline C18:1n-9 & 34.3 & 35.4 & 34.9 & ns & ns & 33.8 & 35.9 & 0.48 & 17.00 & $* * *$ \\
\hline$C 18: 2 n-6$ & 19.7 & 19.3 & 15.2 & $* * *$ & ns & 19.6 & 16.5 & 1.05 & 8.14 & $* *$ \\
\hline C18:3n-3 & 1.9 & 1.8 & 1.5 & $* * *$ & ns & 1.8 & 1.7 & 0.09 & 4.67 & $*$ \\
\hline$\Sigma \mathrm{SFA}$ & 32.3 & 33.0 & 35.1 & $*$ & ns & 33.1 & 33.8 & 1.24 & 0.52 & $\mathrm{~ns}$ \\
\hline$\Sigma$ MUFA & 41.5 & 42.0 & 41.0 & ns & ns & 40.5 & 42.5 & 0.58 & 7.12 & $* *$ \\
\hline $\begin{array}{l}\Sigma \text { PUFA } \\
\text { C18:0 }\end{array}$ & 21.6 & 21.1 & 16.7 & $* * *$ & ns & 21.4 & 18.2 & 1.12 & 8.06 & $* *$ \\
\hline $\mathrm{C} 18: 2^{\ddagger}$ & 0.5 & 0.5 & 0.8 & $* * *$ & ns & 0.5 & 0.7 & 0.06 & 4.21 & $*$ \\
\hline$P: S^{f}$ & 0.7 & 0.7 & 0.5 & $* *$ & ns & 0.7 & 0.6 & 0.05 & 4.64 & $*$ \\
\hline $\begin{array}{l}\text { Total lipic } \\
\text { (g/100g } \\
\text { tissue) }\end{array}$ & $\begin{array}{l}d \\
72.0\end{array}$ & 71.5 & 76.8 & ns & ns & 68.4 & 78.5 & 3.53 & 7.83 & $* *$ \\
\hline
\end{tabular}

Ns: not significant*: $\mathrm{P} \leq 0.05$; **: $\mathrm{P} \leq 0.01 ; * * *: \mathrm{P} \leq 0.001 ;{ }^{\circledR}$ standard error of difference (sed).

${ }^{\ddagger}$ Fat hardness index C18:0/C18:2 2 SFA: total saturated fatty acids

$\sum$ MUFA: total monounsaturated fatty acids; $\sum$ PUFA: total polyunsaturated fatty acids;

${ }^{f}$ Nutritional index $=18: 2+18: 3$

$12: 0+14: 0+16: 0+18: 0$ 


\section{REFERENCES}

1 Wood JD, Richardson RI, Nute GR, Fisher AV, Campo MM, Kasapidou E, Sheard PR and M Enser Effect of fatty acids on meat quality: a review. Meat Sci. 2003; 66: 21-32.

2 Robison OW Harvest endpoints for swine. Proc. Second Inter. Virtual Conf on pork quality-via Internet 2001: 3pp.

3 Latorre MA, Lázaro R, Gracia MI, Nieto M and GG Mateos Effect of sex and terminal sire genotype on performance, carcass characteristics and meat quality of pigs slaughtered at $117 \mathrm{~kg}$ body weight. Meat Science, 2003; 65: 1369-1377.

4 Bonneau $\mathbf{M}$ and EJ Squires Use of entire males for pig production. Proc. $I^{\text {st }}$ Inter. Virtual Conf. on Pork Quality, Concórdia SC, 2000 : 178- 195.

5 Teye GA Present status of, and prospects for meat processing in Ghana. MSc. Thesis, University of Science and Technology, Kumasi, Ghana, 1994. 69pp.

$6 \quad$ Babol J and $\mathbf{J}$ Squires Quality of meat from entire males pigs. Food Res. Inter. 1995; 28 (3): 201-212.

$7 \quad$ Waltra P Fattening of young boars: quantification of negative and positive aspects. Lives.Prod Sci., 1974; 1: 187-196.

8 Malmfors B, Lundström $\mathbf{K}$ and $\mathbf{I}$ Hansson Fatty acid composition of porcine backfact and muscle lipids as affected by sex, weight and anatomical location. Swedish Journal of Agricultural Research, 1978; 8: 25-38.

9 Wood JD, Jones RCD, Francombe MA and OP Whelehan The Effects of Fat thickness and sex on pig meat quality with special reference to the problems associated with overleanness. 2. Laboratory and trained taste panel results. Anim. Prod. 1986; 43: 535-544.

10 Kempster AJ, Dilworth AW, Evans DG and KD Fisher The effects of fat thickness and sex on pig meat quality with special reference to the problems associated with over leanness. 1. Butcher and consumer panel results. Anim. Prod. 1986; 43: 517-533.

11 Wood JD and M Enser Comparison of boar and castrates for bacon production. 2. Composition of muscle and subcutaneous fat, and changes in side weight during curing. Anim. Prod. 1982; 35: 65-74.

12 Gläser KR, Scheeder MRL and C Wenk Fat score, an index value for fat quality in pigs. - it ability to predict properties of backfat differing in fatty acid composition. In: Quality of meat and fat in pigs as affected by genetics and nutrition. EAAP publication. No.100. Zurich, Switzerland, 2000; 203-206.

13 Wood JD, Enser M, Fisher AV, Nute G R, Richardson RI and PR Sheard Manipulating meat quality and composition: animal nutrition and metabolism group symposium on 'Improving meat production for future needs' Proc Nutri Soc. 1999; 58: 363-370.

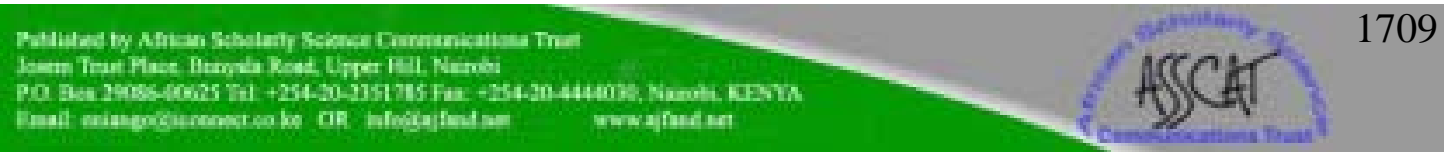


14 Enser M Meat Lipids In: Blackie HRJ (Ed.), Developments in Oils and Fats. Academic and Professional, Glasgow, 1991: 1-31.

15 Nürnberg $\mathbf{K}$, Wegner $\mathbf{J}$ and $\mathbf{K}$ Ender Factors influencing fat composition in muscle and adipose tissue of farm animals. Lives. Prod. Sci. 1998; 56:145-156.

16 Friesen KG, Nelssen JL, Goodband RD, Tokach MD, Unruh JA, Kropf DH and BJ Kerr The effect of dietary lysine on growth, carcass composition and lipid metabolism in high-lean growth gilts fed from 72 to 136kg. J. Anim. Sci. 1995;73, 3392-3401.

17 Cisneros F, Ellis M, Mckeith FK, McCaw J and RL Frnando Influence of slaughter weight on growth and carcass characteristics, commercial cutting and curing yields, and meat quality of barrows and gilts from two genotypes. J. Anim. Sci. 1996; 66: 385-395.

18 Essien AI Chemical fat composition of muscles of indigenous Nigerian pigs as influenced by age and sex. Meat Sci. 1988; 131-142.

19 BSI. 7667 British Standard Institution. Assessors for sensory analysis. Guide to selection, training and monitoring of selected assessors, London, UK, 1993

20 BSI 85/54650. British Standard Institution Animal and Vegetable fats and oilsdetermination of melting point in open capillary tubes (slip point),. London, UK, 1985.

21 Whittington FM, Prescott NJ, Wood JD and M Enser The Effect of dietary linoleic acid on the firmness of backfat in pigs of $85 \mathrm{~kg}$ live weight. J. Sci.\& Food Agric. 1986; 37: 753-761.

22 Hamilton DN, Ellis M, Miller K D, Mckeith FK and DF Parret The effect of halotane and rendement napole genes on carcass and meat quality characteristics of pigs. J. Anim. Sci. 2000; 78: 2862-2867.

23 Blanchard PJ, Ellis M, Warkup CC, Hardy B, Chadwick JP and GA Deans The influence of rate of lean and subcutaneous fat tissue development on pork eating quality. Anim. Sci. 1999; 68: 477-485.

24 Leach LM, Ellis M, Sutton DS, Mckeith FK and ER Wilson The growth performance, carcass characteristics and meat quality of halothane carrier and negative pigs. J. Anim.Sci., 1996; 74: 934-943.

25 Malmfors $\mathbf{B}$ and $\mathbf{R}$ Nilsson Meat quality traits of boars in comparison with castrate and gilt. Swedish Journal of Agricultural Research, 1978; 8: 209-217.

26 Irie M, Ohmoto $\mathbf{K}$ and $\mathbf{K}$ Nishimura Standard measurements for determination of porcine soft fat. Final reports for research grants for meat and meat products. The Ito Foundation, Tokyo, Japan, 1985; 3: 156-164

27 Ellis $\mathbf{M}$ and TM Bertol Effects of slaughter weight on pork and fat quality. Proc. 2nd Inter. Virtual Conf. on Pork Quality, Via Internet. November -December, 2001: 14pp.

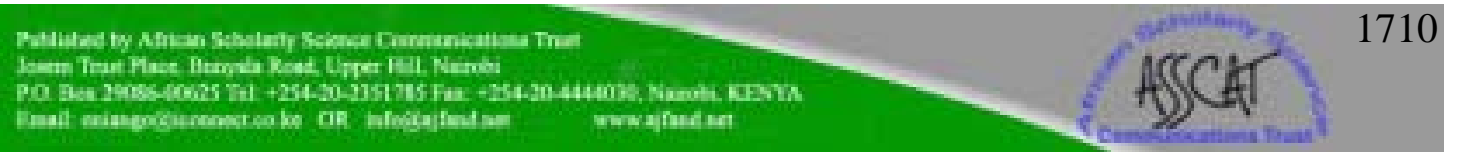


28 Scott RA, Cornelius SG and HJ Mersmann Fatty acid composition of adipose tissue from lean and obese swine. J. Anim. Sci. 1983; 53, (4),977-981.

29 Friend DW, Fortin A, Bulter G, Poste LM, Kramer JKG and VD Burrows Naked oats (Avena Nuda) with and without lysine supplementation, for boars and barrows: growth, carcass and meat quality, energy and nitrogen metabolism. Can. J. Anim. Sci. 1989; 69, 765778. 